J. Dairy Sci. 97:1563-1577

http://dx.doi.org/10.3168/jds.2013-6859

(C) American Dairy Science Association ${ }^{\circledR}, 2014$.

\title{
Precision diet formulation to improve performance and profitability across various climates: Modeling the implications of increasing the formulation frequency of dairy cattle diets
}

\author{
Robin R. White ${ }^{1}$ and Judith L. Capper \\ Department of Animal Sciences, 116 Clark Hall, Washington State University, Pullman 99164
}

\begin{abstract}
The objective of this study was to use a precision nutrition model to simulate the relationship between diet formulation frequency and dairy cattle performance across various climates. Agricultural Modeling and Training Systems (AMTS) CattlePro diet-balancing software (Cornell Research Foundation, Ithaca, NY) was used to compare 3 diet formulation frequencies (weekly, monthly, or seasonal) and 3 levels of climate variability (hot, cold, or variable). Predicted daily milk yield (MY), metabolizable energy (ME) balance, and dry matter intake (DMI) were recorded for each frequency-variability combination. Economic analysis was conducted to calculate the predicted revenue over feed and labor costs. Diet formulation frequency affected ME balance and MY but did not affect DMI. Climate variability affected ME balance and DMI but not MY. The interaction between climate variability and formulation frequency did not affect ME balance, MY, or DMI. Formulating diets more frequently increased MY, DMI, and ME balance. Economic analysis showed that formulating diets weekly rather than seasonally could improve returns over variable costs by $\$ 25,000$ per year for a moderate-sized (300-cow) operation. To achieve this increase in returns, an entire feeding system margin of error of $<1 \%$ was required. Formulating monthly, rather than seasonally, may be a more feasible alternative as this requires a margin of error of only $2.5 \%$ for the entire feeding system. Feeding systems with a low margin of error must be developed to better take advantage of the benefits of precision nutrition.
\end{abstract}

Key words: precision feeding, dairy, climate variability, milk yield

\section{INTRODUCTION}

Precision dairy nutrition has been defined as the use of information technology to optimize economic, social,

Received March 27, 2013.

Accepted November 8, 2013.

${ }^{1}$ Corresponding author: robin.white@email.wsu.edu and environmental farm performance (Spilke and Fahr, 2003). Precision feeding optimizes these performance attributes by facilitating the economically and ecologically sound production of a quality milk product that is highly acceptable to the consumer (Spilke and Fahr, 2003). It is gaining interest as a robust management practice capable of increasing efficiency, reducing costs, improving product quality, minimizing environmental impact, and improving the health and well-being of dairy cattle (Bewley, 2010). Several studies have modeled the effect of precision nutrition on whole-farm nutrient balance (Wang et al., 2000b; Cerosaletti et al., 2004; Ghebremichael et al., 2007; Gehman, 2011). These models indicate that precision nutrition improves dairy productivity by meeting each individual animal's or pens of animals' nutrient requirements more accurately (Wang et al., 2000a; Cerosaletti et al., 2004; Gehman, 2011). On-farm studies have also shown the benefits of precision nutrition. Real-time monitoring of lactating cow feed intake can improve DMI (Halachmi et al., 1998), and on-farm implementation of feeding suggestions from a precision management model can improve milk yield and income over feed costs (Andre et al., 2007). These results indicate that precision feeding may be one method to concurrently improve nutrient-use efficiency and productivity.

To date, few studies have explored the robustness of precision nutrition strategies across variable climates. However, 2 major model systems in dairy nutrition have the capacity to specifically account for additional energy required under conditions of environmental stress (Fox and Tylutki, 1998; NRC, 2001; Fox et al., 2004). The influence of climate on dairy production is well documented (Blackshaw and Blackshaw, 1994; Collier et al., 2006; St-Pierre et al., 2003; West, 2003; Wheelock et al., 2010), and strong evidence indicates that climate variability is increasing (IPCC, 2007; McKibben, 2007; Nardone et al., 2010).

Therefore, the objective of this study was to use a precision nutrition model to simulate the effect of diet formulation frequency on the predicted milk yield (MY), DMI, and ME balance of a representative aver- 
age dairy cow under various climate conditions, and to assess the effect of diet formulation frequency and climate variability on returns over variable costs. We hypothesized that formulating diets more frequently would result in improved ME balance, increased MY, and improved profitability regardless of climate.

\section{MATERIALS AND METHODS}

This study utilized data from existing reports and databases to generate modeled outputs and required no Animal Care and Use Committee approval. Weather data sourced from National Climate Data Center (NCDC, 2010) were entered into the Agriculture Modeling and Training Systems (AMTS) CattlePro diet balancing software. Weather data representing a hot, humid year; a cold, windy year; and a highly variable year were entered on a weekly, monthly, and seasonal basis. Modeled MY, ME balance, and DMI were recorded and compared across weather scenarios and formulation frequencies using a fixed-effects ANOVA. Feed cost and milk price data were sourced from USDA-ERS (2012) and used with modeled MY and DMI to calculate income over feed and labor costs. Results were compared with previously published modeled and measured estimates of climate stress or precision feeding effects on dairy productivity and profitability. To account for variability in feed cost and milk price data, sensitivity analysis on the income over feed and labor cost calculation was conducted.

\section{Generation of Performance Outputs}

Diets were formulated and cattle performance simulated using AMTS CattlePro (AMTS, 2006). CattlePro calculations are based on the Cornell Net Carbohydrate and Protein System (CNCPS; AMTS, 2006). CattlePro was used because it specifically accounts for the influence of environment on nutrient requirements under a wide array of environmental conditions (Fox et al., 2004; Tylutki et al., 2008).

In this study, diets were formulated on a seasonal, monthly, and weekly basis for a lactating Holstein cow to test whether reformulating diets more frequently would increase milk production in an average animal. Nutritional requirements were generated for cows weighing $680 \mathrm{~kg}$ producing $36.5 \mathrm{~kg} / \mathrm{d}$ of milk at 153 DIM, with a milk fat content of $3.8 \%$ and a milk protein content of $3.1 \%$. A full list of input variables used to describe the cows and housing system is included in Table 1. The data describing cows were selected to best simulate an average animal on an operation at any given point during the year. Given the variability in production responses to nutritional modification across lactation and productivity level, it is important to note that these results are the mean predicted response of an average animal and should not be extrapolated to explain the responses of individual cows during different lactation stages or levels of productivity. This study aimed to simulate a freestall housing system; however, in many but not all freestall systems, wind speed (WS) may not have a significant influence upon animal nutrient requirements because of the presence of sheltered areas. In this study, we included WS without accounting for decreases due to sheltered areas or windbreaks. Attenuation of WS was not modeled in this study because insufficient data were available to develop a defendable numerical relationship between WS within a protected freestall system and outside WS. The study may overestimate negative implications of cold stress on dairy cattle in freestall systems and the results may be more applicable to a drylot or pasture-based system. That said, substantial proportions of US operations keep cows in an outside drylot (with or without freestalls; $27 \%$ ) or allow access to pasture (49\%) for some length of time during lactation (USDA-APHIS, 2007).

Feedstuff inputs for diet formulation were sourced from the feedbank in CattlePro (AMTS, 2006). Diets were formulated using an identical base composition (comprising steam-flaked corn grain, corn distillers grains, corn silage, soybean meal, grass hay, and alfalfa hay) with corn grain content varying to meet energy requirements as predicted by CattlePro. Dry hay rather than haycrop silage was selected as a feed in this study because its nutrient content was assumed to be more consistent due to the high variability of DM content in haycrop silage. Diet ingredient composition, $\mathrm{ME}$, and MP values are shown in Table 2. Table 3 shows chemical composition of feedstuffs used. Environmental inputs required for CattlePro included previous and current values for daily temperature (T), WS, and rela-

Table 1. Cow and housing inputs used in diet formulation

\begin{tabular}{lc}
\hline Input & Value \\
\hline Age (mo) & 44.00 \\
Days pregnant (d) & 65 \\
Days since calving (d) & 188 \\
Calving interval (mo) & 14.00 \\
Calf birth weight (kg) & 44 \\
Age at first calving (mo) & 26.10 \\
Milk production (kg/d) & 36.50 \\
Milk fat (\%) & 3.80 \\
Milk true protein (\%) & 3.10 \\
Milk lactose (\%) & 4.78 \\
BCS & 3.00 \\
Housing system & Freestall \\
Hours standing & 12 \\
Number of position changes & 9 \\
Flat distance walked (m) & 300 \\
Sloped distance walked (m) & 1 \\
\hline
\end{tabular}


Table 2. Dietary ingredient composition, energy content, and protein content for each treatment scenario

\begin{tabular}{|c|c|c|c|c|c|c|c|c|}
\hline Scenario & $\begin{array}{l}\text { Corn } \\
(\mathrm{kg})\end{array}$ & $\begin{array}{l}\text { Dried distillers } \\
\text { grains }(\mathrm{kg})\end{array}$ & $\begin{array}{c}\text { Soybean } \\
\text { meal (kg) }\end{array}$ & $\begin{array}{c}\text { Corn } \\
\text { silage (kg) }\end{array}$ & $\begin{array}{c}\text { Grass } \\
\text { hay }(\mathrm{kg})\end{array}$ & $\begin{array}{c}\text { Alfalfa } \\
\text { hay }(\mathrm{kg})\end{array}$ & $\begin{array}{c}\mathrm{ME} \\
(\mathrm{Mcal} / \mathrm{d})\end{array}$ & $\begin{array}{l}\mathrm{MP} \\
(\mathrm{g} / \mathrm{d})\end{array}$ \\
\hline Weekly, hot ${ }^{1}$ & 8.47 & 1.82 & 1.80 & 3.80 & 2.70 & 1.80 & 56.5 & 2,452 \\
\hline Weekly, cold & 8.50 & 1.82 & 1.80 & 3.80 & 2.70 & 1.80 & 56.6 & 2,455 \\
\hline Monthly, hot & 8.41 & 1.82 & 1.80 & 3.80 & 2.70 & 1.80 & 56.3 & 2,446 \\
\hline Monthly, cold & 8.87 & 1.82 & 1.80 & 3.80 & 2.70 & 1.80 & 57.8 & 2,489 \\
\hline Monthly, variable & 8.44 & 1.82 & 1.80 & 3.80 & 2.70 & 1.80 & 56.4 & 2,449 \\
\hline
\end{tabular}

${ }^{1}$ Treatment scenarios included 2 identifiers, 1 indicating the frequency treatment used (weekly, monthly, or seasonally) and 1 indicating the weather treatment (hot, cold, or variable).

tive humidity $(\mathbf{R H})$ and minimum nighttime temperature (Fox et al., 2004). Current conditions predicted the immediate effects of climate on nutrient requirements, and previous conditions accounted for acclimatization of the animal to the conditions (Fox and Tylutki, 1998). When diets were formulated, current conditions referred to the average expected temperature for the feeding period and previous conditions referred to the average temperature in a set period before the feeding period.

Diets were balanced using weekly, monthly, and seasonal (3-mo) periods. When entering weather data, the "current" weather input was used to represent an average year, following the assumption that diet formulators use long-term-average weather data when balancing diets. Daily weather data were averaged over the $10 \mathrm{yr}$ of available data. The "current" weather data entered into CattlePro were the average of this daily average data, representing the time period during which the diet would be fed. The "previous" weather data was the average of the daily data for the period immediately before the period during which the diet would be fed, as it was assumed the diet formulators would have access to these weather data. For the diets using 3-mo periods, the seasons were defined as follows: winter from January 1 to March 31, spring from April 1 to June 30, summer from July 1 to September 31, and fall from October 1 to December 31. Monthly formulation defined seasons by the conventional calendar month. Weekly formulation based periods on 7 -d intervals beginning with January 1.

In each case, required inputs were entered into the model and diets were balanced such that the MEallowable MY was $36.5 \mathrm{~kg} / \mathrm{d}$ and the ME balance was $0.00 \mathrm{Mcal} / \mathrm{d}$. This would represent the best possible scenario (i.e., requirements were predicted perfectly). These points were chosen as reference points, which is what any ration evaluation or formulation program outputs as a target, not because this result is expected to be consistently achieved in the field. Although 0.00 Mcal/d represents precision that is not achievable on most farms, it is the degree of precision allowable within CattlePro. When rations are reformulated in an industry situation, it is assumed that the formulator would adjust the diet to the degree of precision allowed by the diet balancing software. This level of precision was therefore use as a theoretical optimal. After the diet for a time period was balanced, the daily climate data for that period were entered into the program, one day at a time, and the predicted ME balance, MEallowable MY, and the DMI were recorded. At the end of the period, the diet was rebalanced.

\section{Selection of Climate Data}

Weather data for the years between 1999 and 2010 were downloaded from the National Oceanic and Atmospheric Administration database for the weather

Table 3. Dry matter content and nutrient composition of feedstuffs used in diet formulation from Agricultural Modeling and Training Systems (AMTS) feedbank (AMTS, 2006)

\begin{tabular}{|c|c|c|c|c|c|c|c|}
\hline Feedstuff & $\mathrm{DM}(\%)$ & $\mathrm{CP}(\%)$ & Sugar (\%) & Starch $(\%)$ & $\operatorname{ADF}(\%)$ & $\operatorname{NDF}(\%)$ & $\begin{array}{c}\text { Ether } \\
\text { extract }(\%)\end{array}$ \\
\hline Corn & 86 & 9.0 & 1.56 & 75.50 & 3.4 & 23 & 3.67 \\
\hline Dried distillers grains & 91 & 29.7 & 11.61 & 30.18 & 10.0 & 9 & 9.00 \\
\hline Soybean meal & 90 & 51.5 & 10.88 & 2.18 & 6.0 & 10 & 2.80 \\
\hline Corn silage & 35 & 9.2 & 0.80 & 30.87 & 28.0 & 45 & 3.19 \\
\hline Grass hay & 89 & 10.0 & 5.10 & 2.55 & 50.0 & 67 & 3.00 \\
\hline Alfalfa hay & 90 & 20.0 & 9.66 & 1.61 & 32.0 & 40 & 3.00 \\
\hline
\end{tabular}


station in Buffalo, New York (NOAA, 2011). Buffalo was chosen because this location had data available, has a characteristically variable climate, and was close to a high concentration of dairy cattle. Three climate parameters were collected: T, WS, and RH. Examples of extreme and variable weather years were identified and investigated to determine their effects on milk production.

The 3 years with data best suited to the climate scenarios of interest (a hot, humid year; a cold, windy year; and a highly variable year) were identified using a ranking procedure. Figures for the annual mean, 10-yr overall mean, and variance were calculated for T, WS, and RH. Differences between the annual and overall means were calculated (Figure 1) and temperature and $\mathrm{RH}$ were ranked from 1 to 10 with the year with the highest $\mathrm{T}$ and $\mathrm{RH}$ ranked 1 . Wind speed was also ranked from 1 to 10 but the year with the highest value was ranked 10. Rankings for the climate variables were summed for each year and the sum of the rankings was used to determine the hot, humid year and the cold, windy year. The year with the lowest score was selected as the hot, humid year and was expected to have the most extreme combination of high $\mathrm{T}$, high $\mathrm{RH}$, and low WS. The year with the highest score was selected as the cold, windy year and was expected to have the most extreme combination of low T and high WS. To select the highly variable year, the year with the highest cumulative variance was identified. Cumulative variance was calculated as the ratio of the climate parameter variance to the climate parameter mean, summed for all climate parameters ( $\mathrm{T}, \mathrm{RH}$, and WS) within a year. The variance used for this determination is shown in Figure 2. The year best representing a hot, humid climate was 2001 because this year had the second highest $\mathrm{RH}$ and the second highest average $\mathrm{T}$; the year selected as the cold, windy year was 2008 because it had the best combination of low $\mathrm{T}$ and high WS. Climate variability in 2004 was almost twice that in other years (Table 4). Days above or below the thermoneutral zone, as defined by Johnson (1986), were identified for each year. The hot, cold, and variable climates were below thermoneutral $\left(\mathrm{T}<-0.5^{\circ} \mathrm{C}\right)$ for $90 \mathrm{~d}, 100 \mathrm{~d}$, and 102 $\mathrm{d}$ and above thermoneutral $\left(\mathrm{T}>20^{\circ} \mathrm{C}\right)$ for $53 \mathrm{~d}, 39 \mathrm{~d}$, and $49 \mathrm{~d}$, respectively.

\section{Data Analysis}

In this modeling analysis, treatments were applied to time (wk) as the experimental unit: 3 levels of the formulation frequency treatment (weekly, monthly, and seasonally) and each of 3 levels of the climate variability treatment (hot, cold, and variable). This resulted in a $3 \times 3$ factorial design with fixed effects. Data were analyzed using PROC GLM of SAS software (version 9.2; SAS Institute Inc., Cary, NC). Individual analyses were conducted for each response variable. A multivariate ANOVA was used to test how each response variable was affected by formulation frequency and climate

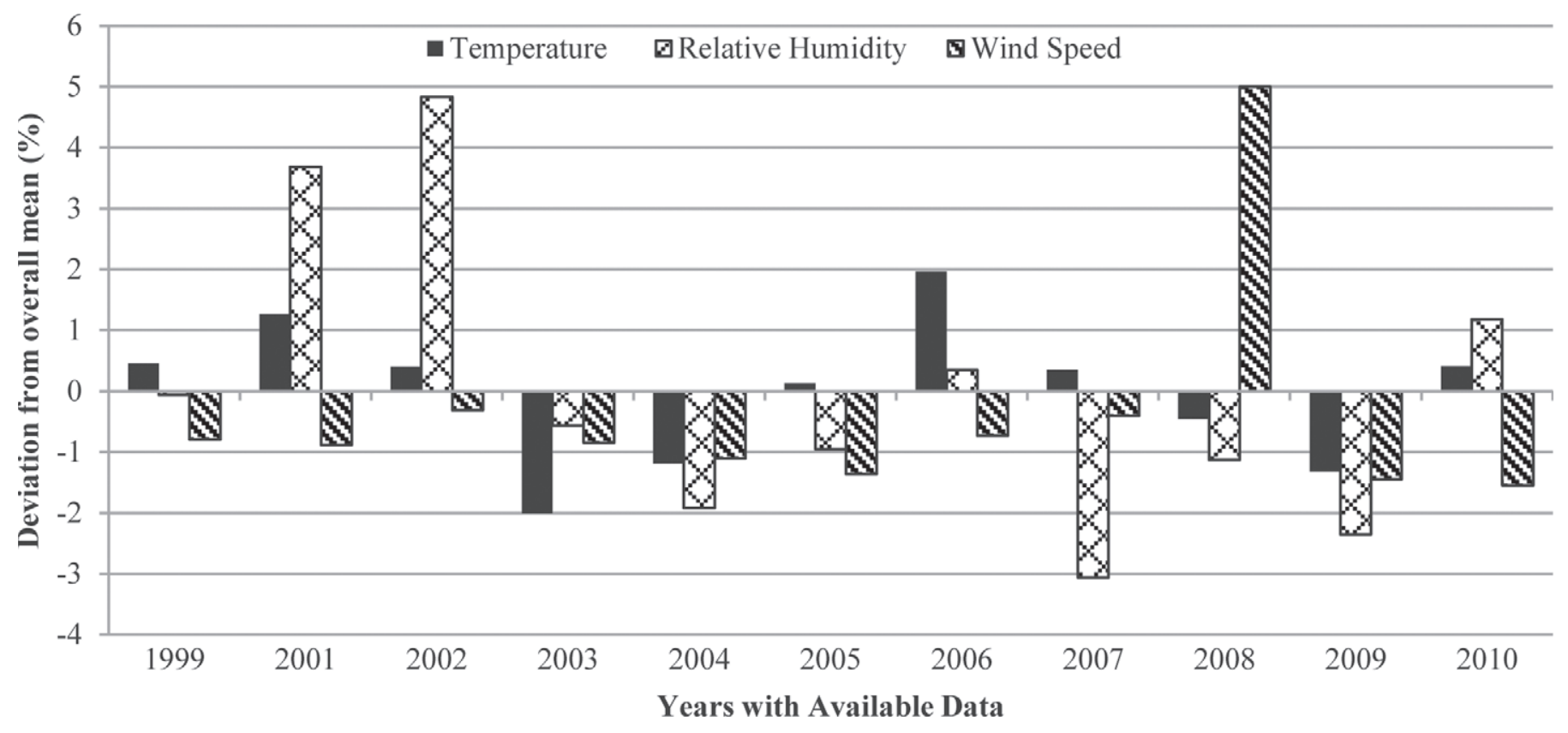

Figure 1. Percentage deviation of yearly temperature, relative humidity, and wind speed from between-year mean values for years between 1999 and 2010 for weather data from Buffalo, New York (NOAA, 2011). 
Table 4. Seasonal temperature, wind speed, and relative humidity for each weather scenario from National Oceanic and Atmospheric Administration database for Buffalo, New York (NOAA, 2011) ${ }^{1}$

\begin{tabular}{lrrr}
\hline Item & Hot & Cold & Variable \\
\hline Winter temperature $\left({ }^{\circ} \mathrm{C}\right)$ & & & \\
$\quad$ Maximum & 10.00 & 13.89 & 12.22 \\
Mean & -1.67 & -2.20 & -3.07 \\
$\quad$ Minimum & -15.00 & -19.84 & -16.67 \\
Summer temperature $\left({ }^{\circ} \mathrm{C}\right)$ & & & \\
$\quad$ Maximum & 28.33 & 22.22 & 28.89 \\
Mean & 20.88 & 16.06 & 21.94 \\
Minimum & 11.11 & 6.67 & 11.67 \\
Winter relative humidity $(\%)$ & & & \\
Maximum & 96.55 & 98.04 & 103.85 \\
Mean & 74.28 & 66.54 & 72.64 \\
Minimum & 0.00 & 0.00 & 0.00 \\
Summer relative humidity $(\%)$ & & & \\
$\quad$ Maximum & 96.36 & 92.49 & 96.92 \\
Mean & 84.03 & 79.30 & 83.86 \\
Minimum & 71.79 & 63.77 & 61.21 \\
Winter wind speed $(\mathrm{km} / \mathrm{h})$ & 33.87 & 37.1 & 32.26 \\
$\quad$ Maximum & 16.13 & 20.13 & 15.23 \\
Mean & 5.16 & 4.52 & 6.13 \\
$\quad$ Minimum & & & \\
Summer wind speed $(\mathrm{km} / \mathrm{h})$ & 29.19 & 26.45 & 29.03 \\
$\quad$ Maximum & 13.77 & 13.78 & 13.34 \\
Mean & 4.68 & 6.61 & 4.84 \\
$\quad$ Minimum & & & \\
\hline
\end{tabular}

${ }^{1}$ The hot scenario used weather data from 2001, the year with the greatest score for high temperature and relative humidity; the cold scenario used weather data from 2008, the year with the greatest score for low temperature and high wind; the variable scenario used weather data from 2004, the year with the greatest variance in weather parameters.

variability. The general linear model used to analyze the effects was as follows:

$$
Y_{i j k}=a_{i}+b_{j}+a b_{i j}+e_{i j k},
$$

where $Y_{i j k}=$ the response of any of the above variables to the $k$ th data point of the ith level of frequency and the $j$ th level of variability; $a_{i}=$ the effect of the $i$ th level of frequency; $b_{j}=$ the effect of the $j$ th level of variability; $a b_{i j}=$ the interaction effect of the $i, j$ treatment combination; and $e_{i j k}=$ the error for the $k$ th data point of the $i, j$ treatment combination. In this model, $i$ contained 3 levels: weekly, monthly, and seasonally; $j$ contained 3 levels: hot, cold, and variable; and $k$ contained 52 values. Data were summed within week. Main effects and interaction terms were generated to visually display the effects of the factors on each response variable. When interactions were significant, the main effects error term could not be used and therefore, interaction terms were examined to ascertain the nature of the effect. For each factor that was found to be significant, Tukey's $95 \%$ confidence intervals were used to differentiate between the levels of that factor. Using the main effect and interaction plots in combination with the results of the Tukey comparisons, the optimal

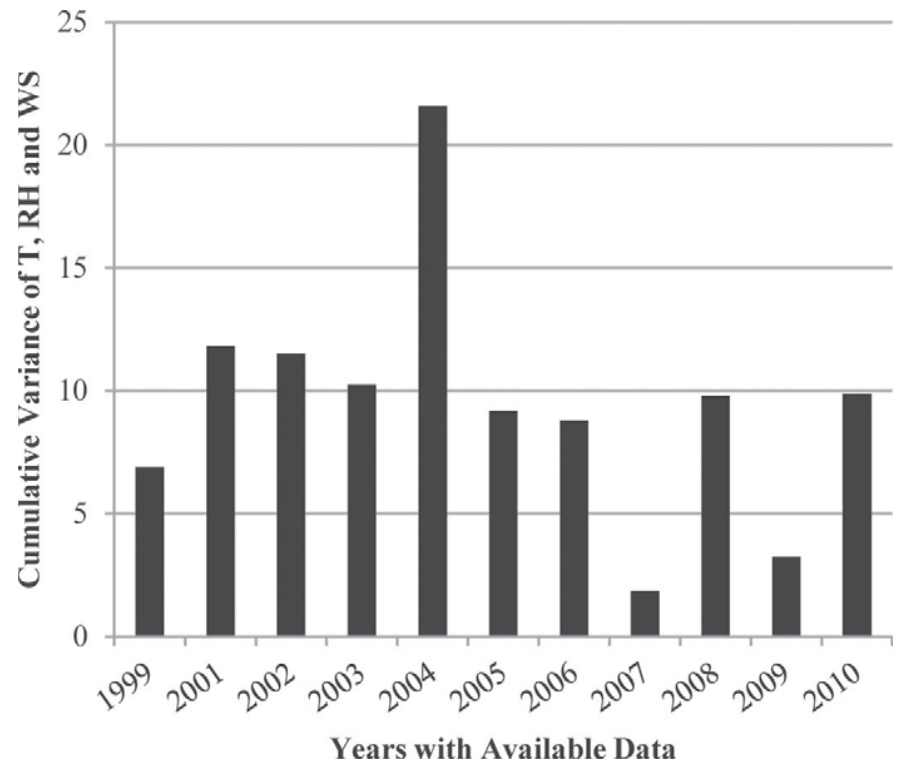

Figure 2. Summed variance of temperature (T), relative humidity $(\mathrm{RH})$, and wind speed (WS) for weather data from Buffalo, New York (NOAA, 2011) for years between 1999 and 2010.

level of diet formulation frequency was determined for each level of climate variability. Significant effects were assumed to occur at $P<0.05$, and trends were defined at $P<0.10$.

\section{Economic Analysis}

To analyze the economics of formulating diets more frequently, costs were assumed to be limited to feed and labor, and milk income (by volume) was the only income source included in the analysis. The cost associated with labor was calculated according to equation [2]:

$$
C_{L, i j}=\Sigma_{t}\left(n_{\text {ref }} \times t_{\text {ref }} \times C_{h l}\right),
$$

where $C_{L, i j}=$ the cost of the labor required to reformulate the diet in the $i, j$ treatment combination; $n_{\text {ref }}=$ the number of times the diet was reformulated; $t_{\text {ref }}=$ the time to reformulate a diet (assumed to be $1 \mathrm{~h}$ ); and $C_{h l}=$ the cost of hourly labor. Mixing was not included as a labor cost because it was assumed to occur daily regardless of diet reformulation frequency or weather patterns. Feed cost and returns over variable costs were calculated daily. Within each level of climate variability, the returns generated by seasonal and monthly formulation were compared with weekly formulation.

\section{Sensitivity Analysis of Economic Simulation}

A sensitivity analysis was performed on the above economic simulation to test the range over which the 
findings held. The parameters used in this analysis were the cost of labor, the price of corn, and the price of milk. The economic simulation described above was conducted using national averages from the year 2011 as base values (USDA-ERS, 2012). The base labor cost was $\$ 40.00 / \mathrm{h}$, the base corn price was $\$ 0.32 / \mathrm{kg}$, and the base milk price was $\$ 0.44 / \mathrm{kg}$. In the sensitivity analysis, the economic simulation was repeated twice, once using a labor cost that was $50 \%$ of the base and again using a labor cost that was $200 \%$ of the base. This process was followed again for the corn prices, simulating once with a corn price $75 \%$ of the base price and once with a corn price at $150 \%$ of the base. Finally, the process was repeated for milk prices. In the case of milk prices, the simulation was conducted once with a price $75 \%$ of the base and once with a price of $150 \%$ of the base. Ranges were selected to represent realistic fluctuations in corn price, labor costs, and milk revenues.

\section{RESULTS AND DISCUSSION}

\section{DMI}

Time-series data for DMI are included in Figure 3. These data appear less variable than the data for milk yield and ME balance shown in Figures 4 and 5 because intake was controlled as part of the formulation frequency treatment. Climate variability $(P<$ 0.01) significantly affected DMI but diet formulation frequency $(P=0.51)$ and the interaction effect did not confer significant effects $(P=0.14$; Table 5$)$. Figure 3 shows that DMI followed similar trends across diet formulation frequency levels; however, the weekly treatment allowed cattle to consume more feed during times of negative energy balance induced by weather variability. Additionally, we found no significant difference in DMI between hot and cold climates $(P>0.05$; Table 6). The consistency of DMI in these climates is shown in Figure 3. Although the lack of a difference appears inconsistent with heat-stress literature, weather conditions in this study were less severe than those typically associated with heat stress. The lack of difference between hot and cold climates could indicate that cattle were not significantly heat-stressed in the hot climate; however, it is more likely that the number of days the cow experienced heat stress may have been insufficient to substantially affect average yearly DMI. West (2003) noted that in the southeastern United States, heat-stress conditions exist for between 4 and 6 mo of the year (120 to $182 \mathrm{~d} / \mathrm{yr}$ ). In this study, heatstress conditions occurred for 39 to $53 \mathrm{~d} / \mathrm{yr}$, depending on the treatment. The less frequent incidence of heat stress modeled in this study may explain why many performance responses predicted were less severe than those reported from studies measuring responses of cattle performance in heat-stress conditions.

Unpredictable climates were the focus of this study because climate predictability is expected to decrease over the next several decades (IPCC, 2007) and erratic climates will negatively affect livestock production (McKibben, 2007). In this study, the treatment representing a variable climate resulted in a higher DMI than either the hot $(P=0.001$; Table 6$)$ or cold $(P=0.003$; Table 6$)$ climates. In the variable climate treatment, cows were simulated to increase daily DMI by $0.28 \mathrm{~kg}$ over DMI simulated in the cold climate, and by $0.30 \mathrm{~kg}$ over DMI simulated in the hot climate. Increased DMI in the variable climate may be due to increased days under the thermoneutral zone. Number of days below the thermoneutral zone was greater in the variable climate treatment $(102 \mathrm{~d})$ than in the cold $(100 \mathrm{~d})$ or hot $(90 \mathrm{~d})$ climate treatments. Cold temperatures cause short-term increases in DMI (Johnson, 1986) and therefore the greater number of days under the thermoneutral zone may have contributed to the increased DMI in the variable scenario. Additionally, Beede and Collier (1986) noted that DMI decreases in lactating dairy cattle are not observed until temperatures exceed $25^{\circ} \mathrm{C}$. The variable climate treatment only included $2 \mathrm{~d}$ when the mean temperature was over $25^{\circ} \mathrm{C}$; therefore, DMI reductions from heat stress would not have been observed in this scenario. This increase in DMI did not confer a statistically significant improvement in milk yield. For a moderate-sized dairy (300 cows), this increase in climate variability would result in a net herd-wide increase in DMI of between 31.4 and 33.4 t/yr. Previous studies have demonstrated that reformulating diets during periods of negative energy balance can improve DMI. West et al. (1999) showed that reduced DMI due to heat stress could be mitigated by increasing dietary NDF concentrations. On average, reformulating the diet on a weekly basis required adding or removing $0.1 \mathrm{~kg}$ of corn grain per head per day. When the diet was reformulated on a monthly basis, reformulation required adding or removing $0.2 \mathrm{~kg}$ of corn grain per head per day. To achieve this level of precision, the cumulative error in the feeding system must be $<1 \%$ by weight. Maximum DMI change was also recorded. In the reformulation with the largest change in intake, DMI was adjusted by $0.83 \mathrm{~kg}$. In reformulation with the greatest DMI change, the feeding system margin of error needed to be $<4 \%$. Although still requiring extreme accuracy from the feeding system, this margin of error is more achievable. The implications of this required precision level are discussed in the Implications and Feasibility section of this study. 
a)
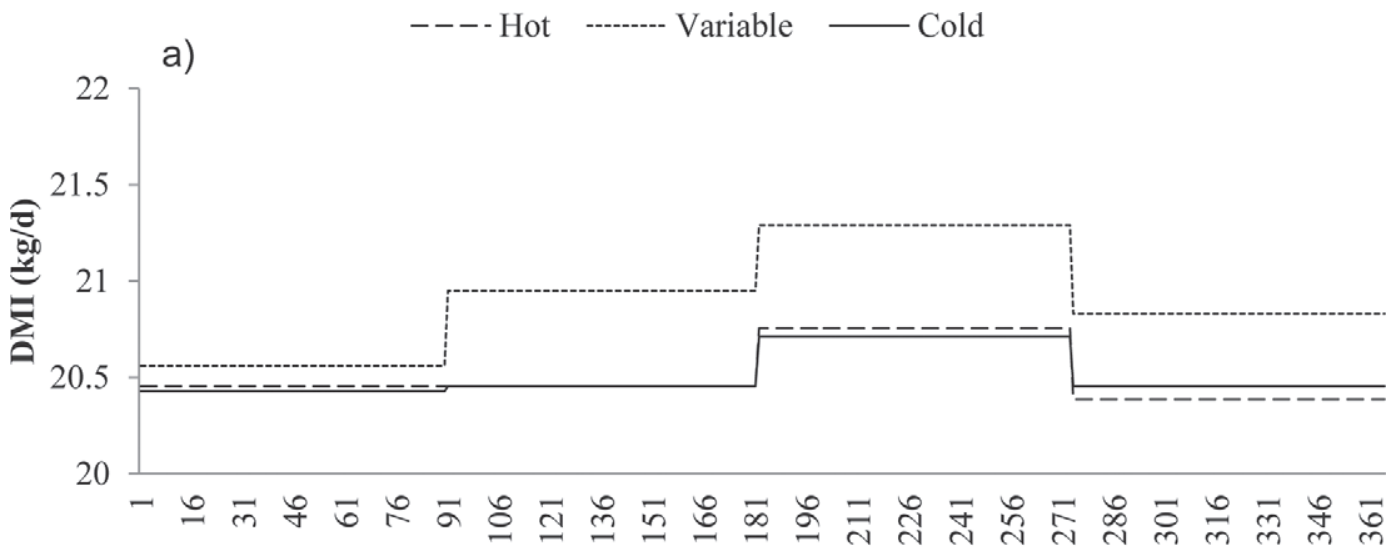

b)

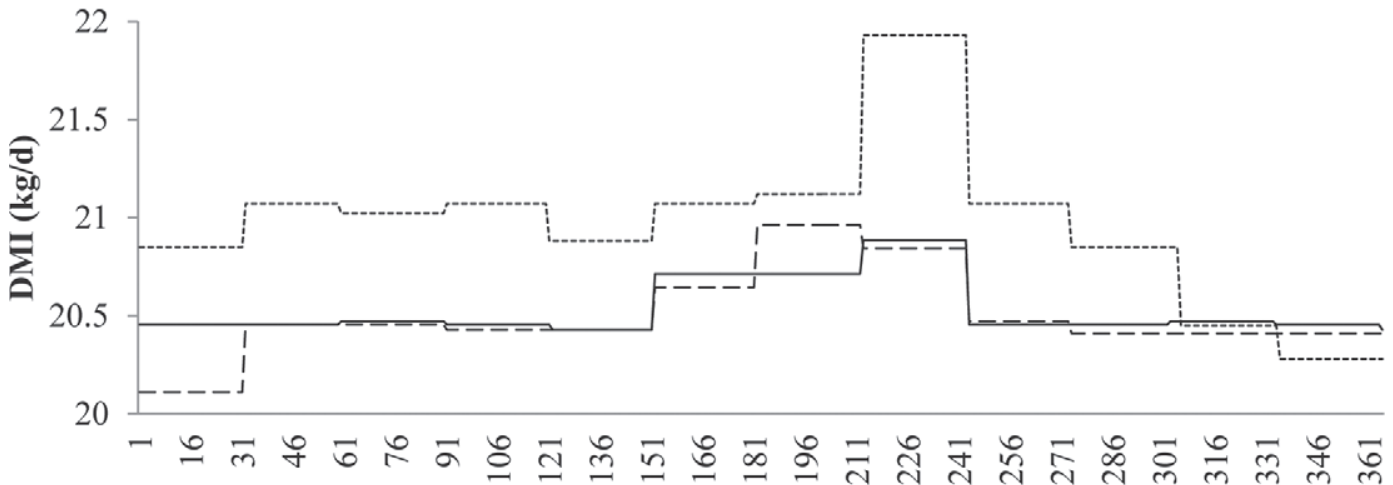

c)

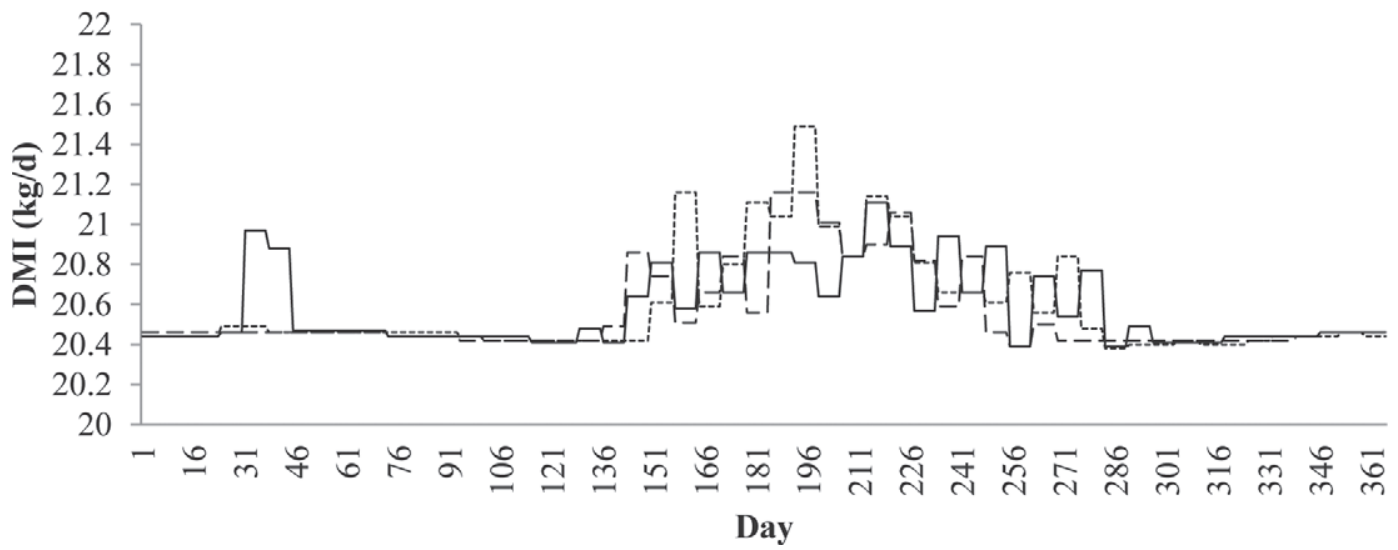

Figure 3. Dry matter intake with (a) seasonal, (b) monthly, and (c) weekly diet formulation in variable, hot, and cold climates.

\section{Milk Yield}

Time-series data of daily MY are included in Figure 4. Diet formulation frequency had a significant influence on MY $(P=0.05)$ but neither climate variability $(P=0.24)$ nor the frequency $\times$ variability interaction $(P=0.21)$ conferred statistically significant differences to MY (Table 5). The hot, cold, and variable climates resulted in yearly average MY of $36.2,36.2$, and 36.0 $\mathrm{kg} / \mathrm{d}$, respectively (Table 5). It is possible that climate variability did not influence milk yield because weather in the years selected was insufficiently severe to effect substantial climate stress. When means were compared across all levels of climate variability, seasonal diet formulation generated lower MY (35.9 kg) than weekly $(36.5 \mathrm{~kg} ; P=0.02)$ or monthly formulation $(36.2 \mathrm{~kg}$; 


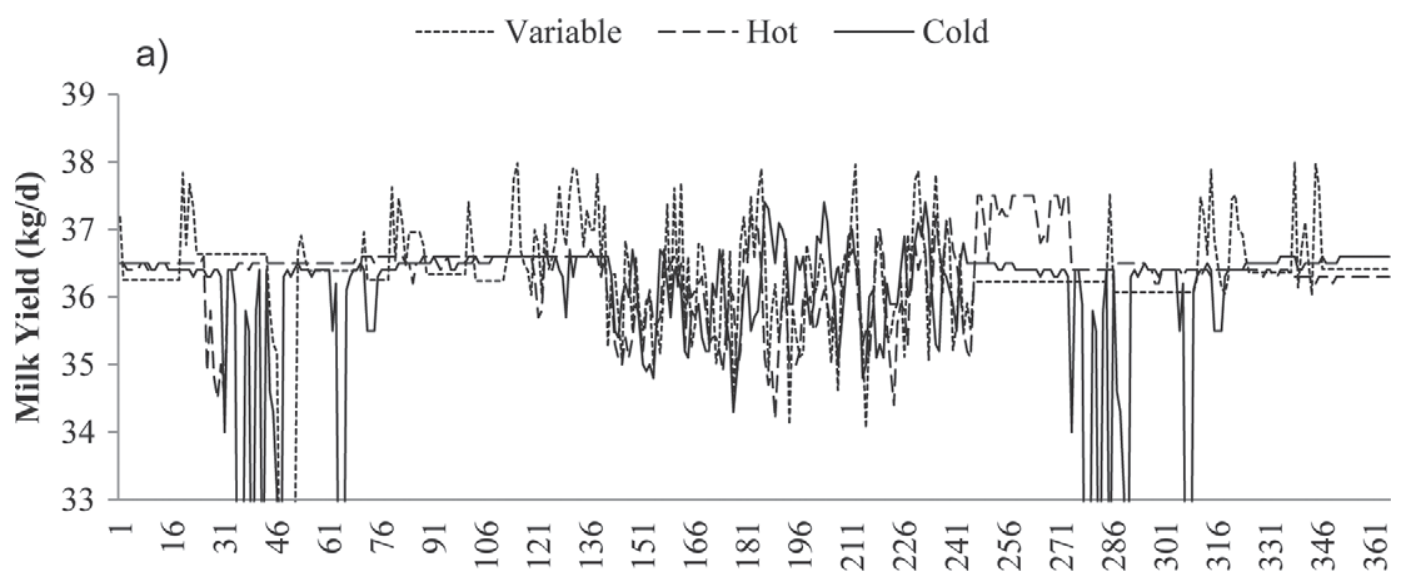

b)

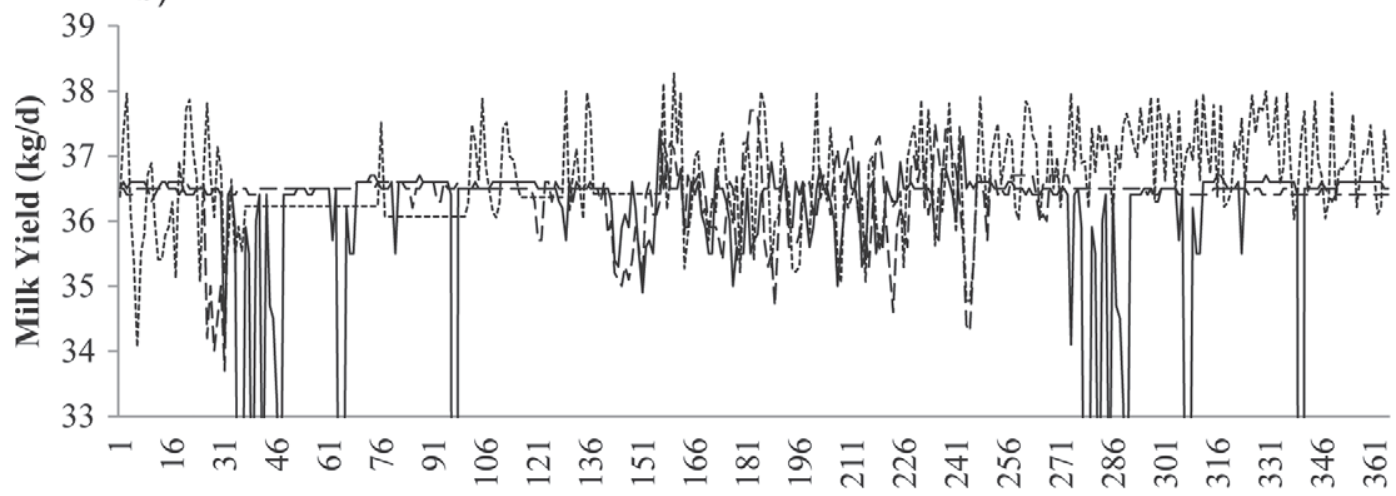

c)

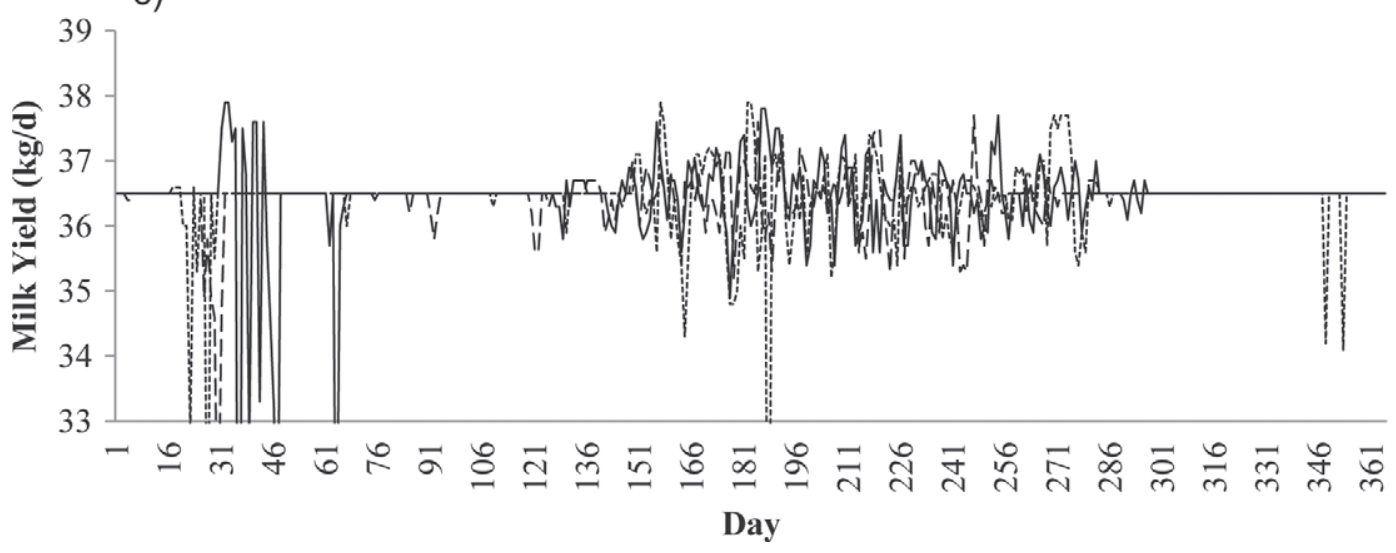

Figure 4. Milk yield with (a) seasonal, (b) monthly, and (c) weekly diet formulation in variable, hot and cold climates.

$P=0.03)$ but monthly and weekly diet formulations were not significantly different $(P>0.05$; Table 6$)$. Figure 4 shows that as diet formulation frequency moved from seasonal to weekly, the variability in daily MY response decreased. Although the mean daily difference in MY was small $(0.59 \mathrm{~kg})$, formulating diets weekly rather than seasonally equated to a $182-\mathrm{kg}$ increase in MY per lactation. When monthly formulation was compared with seasonal formulation, a mean increase of $91.5 \mathrm{~kg}$ of milk per cow per lactation was predicted. For reference, when this average improvement in MY is expanded over the population of a moderate-sized US dairy farm (300 cows; USDA-APHIS, 2007), formulating diets more frequently could improve MY between 27,500 (monthly formulation) and 54,900 (weekly formulation) $\mathrm{kg}$ per year. Variability in response across 
a) ------- Variable ----Hot Cold

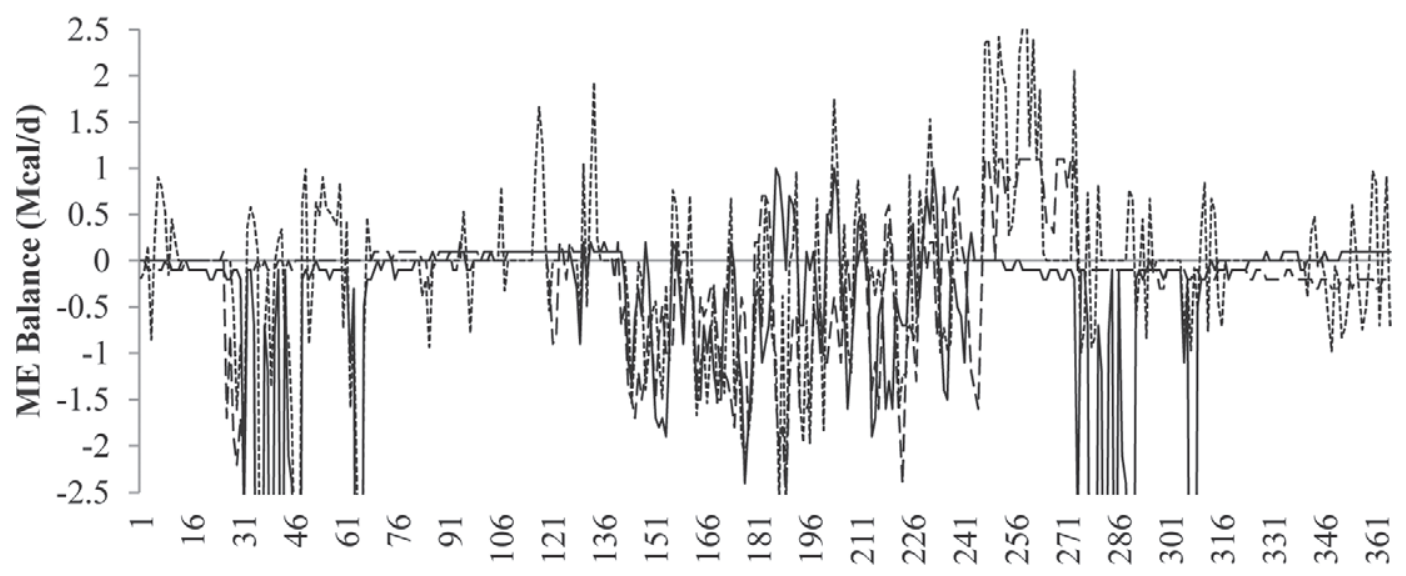

b)

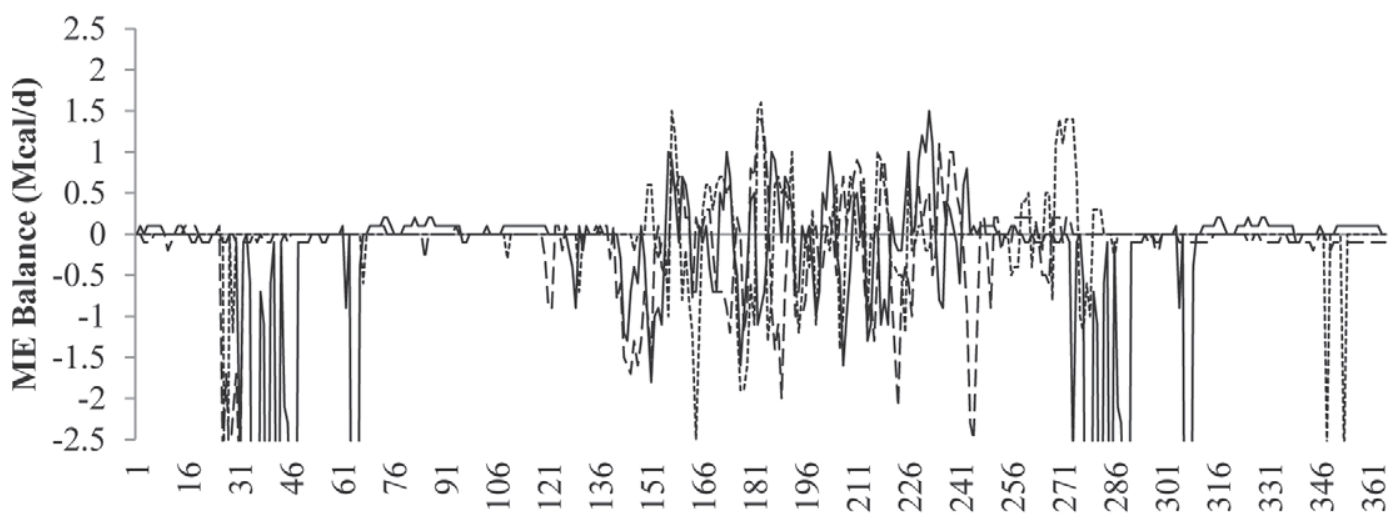

c)

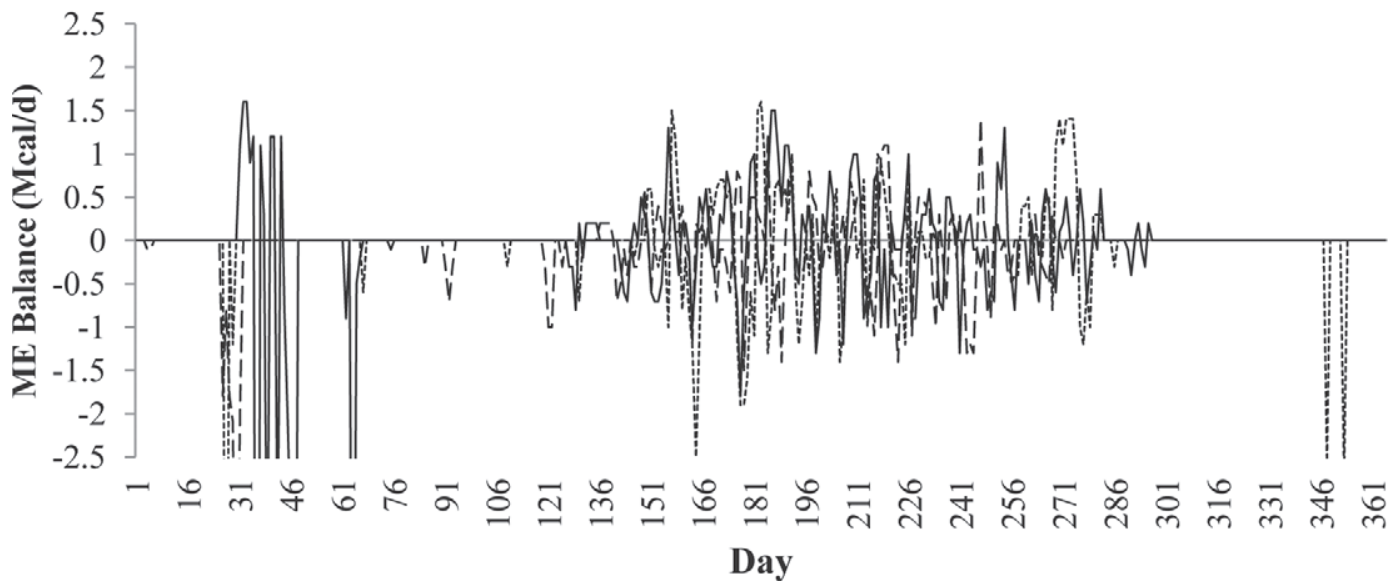

Figure 5. Energy balance with (a) seasonal, (b) monthly, and (c) weekly diet formulation in variable, hot, and cold climates.

lactation, farm size, and productivity level will cause the actual animal response to vary depending on the production characteristics of the population of interest. Data from USDA-APHIS (2007) indicate that milk production improves with herd size. Relationships between milk yield and herd size were not accounted for in this study; however, the target milk production selected was based on an average cow's lactation and 
กิ. Table 5. Mean response of milk yield, ME balance, and DMI under weekly, monthly, or seasonal diet formulations in hot, variable, and cold climates ${ }^{1}$

\begin{tabular}{|c|c|c|c|c|c|c|c|c|c|c|c|c|}
\hline \multirow{2}{*}{$\begin{array}{l}\text { Response } \\
\text { variable }\end{array}$} & \multicolumn{4}{|c|}{ DMI $(\mathrm{kg} / \mathrm{d})$} & \multicolumn{4}{|c|}{ Milk yield (kg/d) } & \multicolumn{4}{|c|}{ ME balance (Mcal/d) } \\
\hline & Weekly & Monthly & Seasonal & Mean & Weekly & Monthly & Seasonal & Mean & Weekly & Monthly & Seasonal & Mean \\
\hline Hot & 20.56 & 20.57 & 20.61 & 20.58 & 36.53 & 36.43 & 36.49 & 36.15 & -0.08 & -0.14 & -0.20 & -0.14 \\
\hline Variable & 21.03 & 20.96 & 20.64 & 20.88 & 36.51 & 36.29 & 35.26 & 36.02 & -0.07 & -0.07 & -0.02 & -0.05 \\
\hline Cold & 20.59 & 20.57 & 20.64 & 20.60 & 36.53 & 36.00 & 36.03 & 36.19 & -0.08 & -0.35 & -0.51 & -0.31 \\
\hline \multirow[t]{2}{*}{ Mean } & 20.73 & 20.70 & 20.63 & & 36.52 & 35.91 & 35.93 & & -0.07 & -0.19 & -0.24 & \\
\hline & $\mathrm{F}$ & V & $\mathrm{F} \times \mathrm{V}$ & & $\mathrm{F}$ & V & $\mathrm{F} \times \mathrm{V}$ & & $\mathrm{F}$ & $\mathrm{V}$ & $\mathrm{F} \times \mathrm{V}$ & \\
\hline$P$-value ${ }^{2}$ & 0.51 & 0.0004 & 0.14 & & 0.05 & 0.24 & 0.20 & & 0.04 & 0.0006 & 0.08 & \\
\hline
\end{tabular}

${ }^{1}$ Mean values for each treatment combination are listed first. Standard error of DMI, milk yield and ME balance responses were 0.089, 0.207, and 0.197, respectively.

${ }^{2} P$-values associated with formulation frequency $(\mathrm{F})$, variability $(\mathrm{V})$ in climate, and their interaction $(\mathrm{F} \times \mathrm{V})$ in the ANOVA.

Table 6. Significance values ( $P$-values) of between-level differences for frequency and variability effects on milk yield, DMI, and ME balance

\begin{tabular}{|c|c|c|c|c|c|c|c|c|c|c|c|c|c|}
\hline \multirow[b]{3}{*}{ Level $^{1}$} & \multicolumn{6}{|c|}{ Frequency } & \multirow[b]{3}{*}{ Level $^{2}$} & \multicolumn{6}{|c|}{ Variability } \\
\hline & \multicolumn{3}{|c|}{ Milk yield } & \multicolumn{3}{|c|}{ ME balance } & & \multicolumn{3}{|c|}{ ME balance } & \multicolumn{3}{|c|}{ DMI } \\
\hline & Week & Month & Season & Week & Month & Season & & Hot & Cold & Var. & Hot & Cold & Var. \\
\hline Week & - & 0.56 & 0.02 & - & 0.67 & 0.04 & Hot & - & 0.01 & 0.03 & - & 0.97 & 0.001 \\
\hline Month & 0.56 & - & 0.03 & 0.67 & - & 0.24 & Cold & 0.01 & - & 0.43 & 0.97 & - & 0.003 \\
\hline Season & 0.02 & 0.03 & - & 0.04 & 0.24 & - & Var. & 0.03 & 0.43 & - & 0.001 & 0.003 & - \\
\hline
\end{tabular}

${ }^{1}$ Levels in the frequency treatment (weekly, monthly and seasonal diet formulations) are represented by week, month and season, respectively.

${ }^{2}$ Levels in the variability treatment (hot, cold, and variable climates) are represented here by hot, cold and var., respectively. 
therefore should be representative of an average-sized herd. Milk production per cow modeled in this study was similar to average production on a 300-head operation in the northeastern United States, as reported by Lidback and Laughton (2012).

Few studies exist that assess the effect of diet formulation frequency on MY; therefore, alternative data were sought to ensure the feasibility of the changes predicted by the current study. Reductions in MY due to heat-stress periods in this study were lower than those presented by other studies reporting the effect of heat stress on milk production. Hahn and Osburn (1969) reported that in geographic locations typically associated with heat stress, the decline in milk production in the period from June 1 through September 30 was 1.5 to $2.2 \mathrm{~kg} / \mathrm{d}$ over the 4 -mo period. Klinedinst et al. (1993) modeled the effect of heat stress on milk production between May 1 and September 30. Over that 5-mo period, MY was predicted to reduce by between 2.0 and $5.9 \mathrm{~kg} / \mathrm{d}$ depending on the severity of heat stress. Hahn and Nienaber (1976) reported expected milk production losses of 95 to $268 \mathrm{~kg} / \mathrm{yr}$, depending on weather severity. In comparison, West (2003) noted that actual MY losses were between 4.6 and $7.1 \mathrm{~kg}$ in the southern United States, much higher than losses predicted in most previous studies. Within the current study, when seasonal formulation MY was compared with input MY (36.5 kg/head per day), calculated losses during the summer period (May 1 to September 30) ranged from 0.11 to $0.37 \mathrm{~kg} / \mathrm{d}$ and averaged $0.26 \mathrm{~kg} / \mathrm{d}$. The discrepancy between the magnitudes of the reduction in MY over the summer period between the current study and other published studies may be attributed to differences in study location. Figure 4 shows the decrease in MY during the summer months compared with the remainder of the year. When using a thermoneutral zone upper bound of $20^{\circ} \mathrm{C}$ (Johnson, 1986), the hot climate was only above the thermoneutral zone for 53 d. Most studies of heat stress in dairy cattle use herds based in the southeastern United States because of the severity of heat and humidity (West, 2003), and days above thermoneutral in that region are generally much greater than were observed in this study. As such, although MY decline induced by heat stress was predicted on days with severe weather, when summed over a full year, the effects of this stress were much lower than seen in most studies occurring in locations where the number of heat-stress days is substantially greater.

The reductions in MY seen during periods of cold stress are less than those observed during heat stress because dairy cattle are more tolerant of cold stress than they are of heat stress (Blaxter, 1958; Young, 1981). In a study comparing average to cold temperatures, Broucek et al. (1991) reported that mean milk produc- tion decreased by $1.16 \mathrm{~kg}$ when $\mathrm{T}$ decreased to $-10^{\circ} \mathrm{C}$, and by $2.21 \mathrm{~kg}$ when $\mathrm{T}$ decreased to $-17^{\circ} \mathrm{C}$. Changes in MY due to cold stress predicted by our study were also lower than those identified in previous studies. Under seasonal formulation, analysis of the raw data indicated that, on average, when $\mathrm{T}$ decreased to between $-9^{\circ} \mathrm{C}$ and $-11^{\circ} \mathrm{C}$, MY did not change from the input value (36.5 kg/head per day). Conversely, when $\mathrm{T}$ decreased to between $-16^{\circ} \mathrm{C}$ and $-17^{\circ} \mathrm{C}$, MY decreased by 0.2 to 1.5 $\mathrm{kg} /$ head per day compared with the input value $(36.5$ $\mathrm{kg} /$ head per day). Figure 4 shows that cold-stress periods resulted in specific days with substantial decreases in performance rather than a general period with decreased performance, as is observed for heat stress during the summer. Measured decreases in MY due to cold stress could have been because Broucek et al. (1991) measured responses of heifers to decreased temperature, whereas cows were modeled in this study. The additional energy requirement for growth of heifers may have amplified the effect of cold stress on milk yield.

The effects of precision nutrition management on milk production have been estimated by several researchers. Cerosaletti et al. (2004) reported MY changes from -0.4 to $+1.8 \mathrm{~kg} / \mathrm{d}$ when precision nutrition management was implemented. Within the current study, modeled improvements in MY $(0.59 \mathrm{~kg} / \mathrm{d})$ conferred by balancing diets weekly or monthly rather than seasonally were within the range previously reported. This improvement held across all levels of climate variability and therefore indicate that precision feeding by more frequent diet formulation could present a reasonable mitigation strategy to preserve MY across a wide climatic range.

\section{ME Balance}

Diet formulation frequency $(P=0.04)$ and the effect of climate variability $(P<0.01)$ significantly affected ME balance. We observed a tendency for an interaction between formulation frequency and climate variability $(P=0.08$; Table 5$)$. The effects of weather variability and formulation frequency on ME balance are clearly demonstrated in Figure 5. The highly variable climate had substantially more variability in ME balance than the hot and cold climates. As formulation frequency was increased from seasonal to weekly formulation, the magnitude of the variability in ME balance response decreased. Seasonal diet formulation resulted in an ME balance that was $0.16 \mathrm{Mcal} / \mathrm{d}$ less than weekly diet formulation $(P=0.04$; Table 6$)$. Cold $(P<0.01)$ and hot $(P=0.03)$ climates resulted in ME balances that were 0.26 and $0.09 \mathrm{Mcal} / \mathrm{d}$ less than the variable climate, but no significant difference was detected between hot and cold climates $(P>0.05$; Table 6$)$. No 
significant difference between hot and cold climates was expected because mechanisms to maintain body temperature within the thermoneutral zone require energy (Beede and Collier, 1986). During times of heat stress, the biology of a dairy cow relies on energy-intensive heat abatement strategies such as panting and sweating (West, 2003). Similarly, during cold stress, shivering thermogenesis relies on the utilization of energy (Young, 1983). Hot and cold climates resulted in more negative ME balances than the variable climate. This was surprising because the fluctuations in ME balance caused by both extreme hot and extreme cold weather in the variable climate were expected to compound to a more negative ME balance. This result may be related to the use of average weather data to formulate diets for seasonal and monthly treatments. Weather fluctuations in the variable climate may have caused average weather data used to generate diets to skew toward either the extreme cold (during winter) or the extreme hot (during summer). The amount of dietary $\mathrm{ME}$ required to compensate for ME losses due to hotter or colder weather would increase. On days with moderate weather, the diet balanced would have an excess of $\mathrm{ME}$, meaning that cows would have been in a positive energy balance more frequently. An alternative explanation of the ME balance dynamics could be related to the days outside the thermoneutral zone. The variable climate resulted in a total of $151 \mathrm{~d}$ outside the thermoneutral zone, whereas the hot and cold climates were outside the zone for 143 and $139 \mathrm{~d}$, respectively. The more negative $\mathrm{ME}$ balance seen in the variable climate was likely due to the difference in total days outside the thermoneutral zone.

The differences in ME balance reported in Table 5 appear to require precision that is not only unobtainable on-farm but outside the reliable range of prediction for most ME balance equations. Margins of error around ME requirements per kilogram of metabolic BW have been estimated at between 7\% (Strathe et al., 2011) and $11 \%$ (Kebreab et al., 2003), whereas the values in Table 5 vary by $<1 \%$. The values in Table 5 are yearlyaverage ME balances. Across an entire year of data, most individual days did not return ME balances that were different from $0.00 \mathrm{Mcal} / \mathrm{d}$, and, as such, these yearly-average data are not representative of the actual daily ME dynamics that drove the results predicted in this study. For comparison, on days when ME balance was negative, actual reductions in daily ME balance ranged from -0.2 to $-25.7 \mathrm{Mcal} / \mathrm{d}$. The actual daily change in ME balance is shown in Figure 5. When converted to a percentage difference in energy requirement, these ME balances equate to a range of 0.3 to $45.3 \%$ per $\mathrm{kg}$ of metabolic BW. Given the above error estimates, the lower end of the range in $\mathrm{ME}$ balance is not reliably different from $0.00 \mathrm{Mcal} / \mathrm{d}$; however, the majority of the range extends well past the 7 to $11 \%$ error bound. Although the ME balances reported in this study may appear to rely on unrealistic precision, many of the actual daily differences represent changes that are substantial and should be measurable on-farm.

\section{Economic Analysis}

Economic analysis revealed a substantial decrease in returns over feed and labor costs when diets were formulated less frequently (Figure 6). On average, producers were predicted to lose $\$ 68.65 /$ head per year when diets were formulated seasonally rather than weekly and $\$ 39.38 /$ head per year when formulating seasonally rather than monthly (Figure 6). Nearly $60 \%$ of the losses associated with formulating seasonally rather than weekly could be recouped by formulating monthly. These changes in returns over feed and labor costs are within the range identified by previous studies modeling the economics of precision nutritional management (Ghebremichael et al., 2007). On average, the cold climate had the greatest loss from formulating less frequently, followed by the hot climate. The variable climate had the lowest loss from formulating less frequently. These dynamics are directly caused by the differences in MY and DMI in the different scenarios. Milk price was the most sensitive parameter within the economic analysis. Increasing corn grain to $150 \%$ of the average price decreased returns over feed and labor costs by $\$ 35.10 /$ head per year. Decreasing corn grain price to $75 \%$ of the average price increased returns over feed and labor costs by $\$ 16.43 /$ head per year. By comparison, returns over feed and labor costs decreased $\$ 55.75 /$ head per year or increased $\$ 26.75 /$ head per year when milk price varied between 75 and $150 \%$ of the base price. Similarly, decreasing labor costs to $50 \%$ of the base scenario increased returns over feed and labor costs by $\$ 6.66 /$ head per year, whereas increasing labor costs to $200 \%$ of the base scenario decreased returns over feed and labor costs by $\$ 3.32 /$ head per year. The range of outputs calculated in this sensitivity analysis is shown in Figure 7. Feed and milk prices had the greatest influence on profitability. Feed cost is generally acknowledged as the single largest variable cost on animal operations and therefore this result is not surprising. Furthermore, milk production was the only source of revenue tracked in this assessment and therefore, it would be expected that milk price would have a substantial influence on returns over feed and labor costs.

\section{Implications and Feasibility}

A previous study assessing various precision management scenarios identified changes in returns over feed 


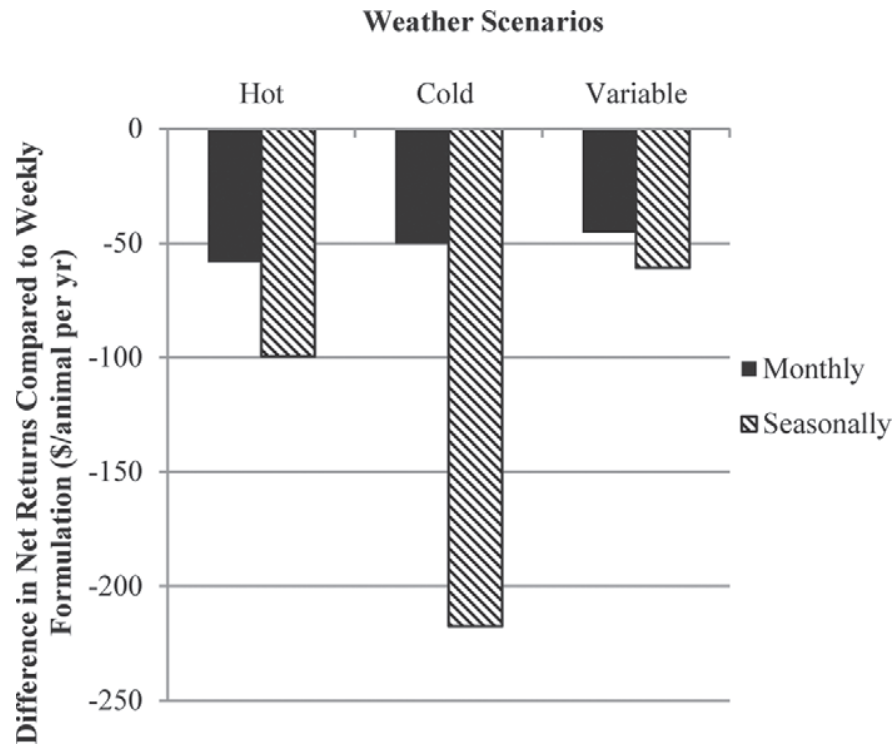

Figure 6. Expected differences in returns over feed and labor costs for formulating diets monthly (diets reformulated every $30 \mathrm{~d}$ ) or seasonally (diets reformulated every $90 \mathrm{~d}$ ) compared with formulating diets weekly.

and labor costs of between $\$ 12$ and $\$ 186 /$ head per year associated with implementing precision dairy management (Ghebremichael et al., 2007). On a moderate-sized dairy (300 cows), these increases equated to a $\$ 3,600$ to $\$ 55,800$ per year improvement in returns. Within the current study, changes in returns over feed and labor costs of between $\$ 39.38$ and $\$ 68.65 /$ head per year were revealed by formulating diets more frequently. When scaled up to a moderate-sized dairy (300 cows), the calculated predicted increase in returns over feed and labor costs ( $\$ 14,400$ to $\$ 25,000$ per year) was slightly lower than the range outlined by Ghebremichael et al. (2007). This may be due to differences in the type of precision management tested; Ghebremichael et al. (2007) assessed crop management practices in addition to precision diet formulation and delivery mechanisms, whereas the current study focused only on precision diet formulation. Additionally, economic metrics are highly dependent on specific data (e.g., location, feedstuffs used, year) and therefore, differences in returns over feed and labor costs outlined in this study compared with other studies of precision feeding are most likely explained by study-specific differences rather than variability in the effectiveness of management. The increase in returns over feed and labor costs predicted in this study represents a substantial improvement for a moderate-sized (300 cow) dairy.

Before advocating precision diet reformulation as a viable method to mitigate productivity changes conferred by climate stress, the ability to achieve the predicted profit increases on-farm should be investigated.
Mean DMI was $20.6 \mathrm{~kg}$ and, on average, a reformulation changed DMI by $0.2 \mathrm{~kg}$. Minimum change in DMI during a reformulation event was $0.006 \mathrm{~kg}$, whereas maximum DMI change was $0.86 \mathrm{~kg}$. To feed a ration differing by $0.2 \mathrm{~kg}$ per cow requires a scale sensitive enough to detect a difference of $60 \mathrm{~kg}$ in a feed batch totaling $6,180 \mathrm{~kg}$. The cumulative margin of error required of the feeding system (feed analysis, diet formulation, weighing, mixing, transportation, feeding, and consumption) to use this level of precision feeding must be much less than $1 \%$ by weight. Before frequently reformulating diets can be advocated as an economically sound management practice, further investigation should be conducted into the feeding system margin of error.

Although estimates of imprecision in weighing mixing, transport, and feeding are difficult to identify, estimates of feed analysis, diet formulation, and consumption variability are available. In an analysis of $\mathrm{CP}$ and fat content of whole cottonseed analyzed by Purina Mills from 1988 through 1996, the mean coefficients of variation around protein content $(11.9 \%)$ and fat content $(16.9 \%)$ were sufficient to significantly alter diet composition (Kertz, 1998). The most variable feed component is arguably DM content. Weiss et al. (2012) reported that the coefficient of variation of silage DM content ranged from 7.8 to $14.7 \%$. Coefficient of variation of hay DM content was $2.8 \%$ and that of concentrate DM content ranged from 1 to $7.4 \%$. The results

\section{Parameters Varied for Sensativity Analysis}

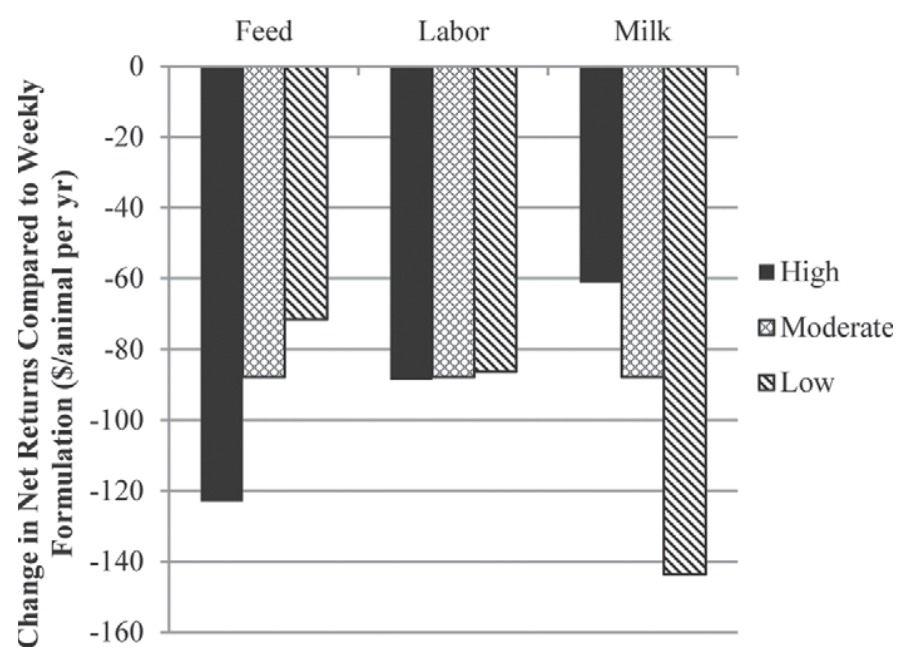

Figure 7. Sensitivity analysis of economic output under 3 levels of feed costs, labor costs, and milk price. Feed costs and milk price were varied between 75 and $150 \%$ of their base value; labor costs were varied between 50 and $200 \%$ of the base. The high bars refer to the scenario where the value was adjusted to 150 or $200 \%$ of the base; the low bars reflect the scenario where the value was adjusted to 50 or $75 \%$ of the base; and the moderate bars show the base scenario. 
in this study depend on the accuracy of feed analysis and as such, precision diet formulation would require frequent feed analysis. As previously addressed, the variability around estimates of ME requirements range from $7 \%$ (Strathe et al., 2011) to $11 \%$ (Kebreab et al., 2003). In an initial validation, the energy requirements predicted by CNCPS had a bias of only $4 \%$ (Fox et al., 1992). Although these error ranges are better than previous energy prediction systems, improved accuracy in energy prediction would improve results seen from formulating diets more frequently. Dry matter intake is also known to vary considerably. When CNCPS DMI predictions were compared with observed DMI for lactating Holstein cows, the standard error of intake was $1.7 \mathrm{~kg}$ when mean intake was approximately $20 \mathrm{~kg} / \mathrm{d}$, an $8 \%$ error (Fox et al., 1992). Together, estimates of individual error in feed analysis, energy requirement, and DMI prediction range from 4 to $17 \%$. Implementation of more comprehensive precision nutrition management by controlling these sources of variation and improving precision of feed mixing, transportation, and delivery systems will improve results seen from formulating diets more frequently. The results of this study indicate that formulating diets more frequently can theoretically control for weather variability to help improve cow performance and profitability. Improved estimates of feedstuff composition, prediction equations for animal requirements, and mixing and delivery machinery are necessary for these theoretical results to be realistically achievable.

\section{CONCLUSIONS}

Formulating diets more frequently across a range of climates allowed the energy requirements of dairy cattle to be met more precisely, thereby increasing milk production efficiency. Economic analysis indicated that formulating diets more frequently generally increased profitability, because any increase in feed cost was mitigated by an increase in profitability through improved MY. The margins of error of average feeding systems used in the industry are unknown; however, considering the aggregated opportunity for error during weighing, mixing, transport, storage, and feeding, the error is expected to appreciate. To fully reap the potential benefits of precision diet formulation, more accurate weighing and delivery machinery in dairy feeding systems should be adopted because the overall margin of error required for the entire feeding system is $<1 \%$. Given the limitations on the typical feeding system used in the industry today and the results of this study, monthly diet formulation appears to be the best compromise to increase efficiency within the achievable bounds of today's dairy farm infrastructure.

\section{REFERENCES}

AMTS (Agricultural Modeling and Training Systems). 2006. AMTS CattlePro. Version 3.3. Cornell Research Foundation, Ithaca, NY.

Andre, G., W. Ouweltjes, R. L. G. Zom, and E. J. B. Bleumer. 2007. Increasing economic profit of dairy production utilizing individual real time process data. Pages 179-186 in Precision Livestock Farming. S. Cox, ed. Wageningen Academic Publishers, Wageningen, the Netherlands.

Beede, D. K., and R. J. Collier. 1986. Potential nutritional strategies for intensively managed cattle during thermal stress. J. Anim. Sci. 62:543-554.

Bewley, J. 2010. Precision dairy farming: Advanced analysis solutions for future profitability. Pages 1-8 in Proc. First North Am. Conf. Precision Dairy Management, Toronto, Ontario, Canada. Progressive Dairy Operators, Guelph, Ontario, Canada.

Blackshaw, J. K., and A. W. Blackshaw. 1994. Heat stress in cattle and effect of shade on production and behaviour: A review. Aust. J. Exp. Agric. 34:285-295.

Blaxter, K. L. 1958. Nutrition and climate stress in farm animals. Proc. Nutr. Soc. 17:191-197.

Broucek, J., M. Letkovicova, and K. Kovalcuj. 1991. Estimation of cold stress effect on dairy cows. Int. J. Biometeorol. 35:29-32.

Cerosaletti, P. E., D. G. Fox, and L. E. Chase. 2004. Phosphorus reduction through precision feeding of dairy cattle. J. Dairy Sci. 87:2314-2323.

Collier, R. J., G. E. Dahl, and M. J. VanBaale. 2006. Major advances associated with environmental effects on dairy cattle. J. Dairy Sci. 89:1244-1253.

Fox, D. G., C. J. Sniffen, J. D. O'Connor, J. B. Russell, and P. J. Van Soest. 1992. A net carbohydrate and protein system for evaluating cattle diets: III. Cattle requirements and diet adequacy. J. Anim. Sci. 70:3578-3596.

Fox, D. G., L. O. Tedeschi, T. P. Tylutki, J. B. Russell, M. E. Van Amburgh, L. E. Chase, A. N. Pell, and T. R. Overton. 2004. The Cornell Net Carbohydrate and Protein System model for evaluating herd nutrition and nutrient excretion. Anim. Feed Sci. Technol. 112:29-78.

Fox, D. G., and T. P. Tylutki. 1998. Accounting for the effects of environment on the nutrient requirements of dairy cattle. J. Dairy Sci. 81:3085-3095.

Gehman, A. M. 2011. Enhanced nitrogen utilisation in dairy cattle with precision protein nutrition. Rec. Adv. Anim. Nutr. 18:187195.

Ghebremichael, L. T., P. E. Cerosaletti, T. L. Veith, C. A. Rotz, J. M. Hamlett, and M. J. Gburek. 2007. Economic and phosphorusrelated effects of precision feeding and forage management at a farm scale. J. Dairy Sci. 90:3700-3715.

Hahn, G. L., and J. A. Nienaber. 1976. Summer weather variability and livestock production. Trans. Am. Soc. Agric. Biol. Eng. $57: 32$.

Hahn, G. L., and D. D. Osburn. 1969. Feasibility of summer environmental control for dairy cattle based on expected production losses. Trans. Am. Soc. Agric. Biol. Eng. 13:448-451.

Halachmi, I., Y. Edan, E. Maltz, U. M. Peiper, U. Moallem, and I. Brukental. 1998. A real-time control system for individual dairy cow food intake. Comput. Electron. Agric. 20:131-144.

IPCC (Intergovernmental Panel on Climate Change). 2007. Climate Change 2007-Synthesis Report. IPCC, Geneva, Switzerland.

Johnson, D. 1986. Climatic stress and production efficiency: Limiting effects of stress on cattle. Western Region. Res. Publ. 9:17-20.

Kebreab, E., J. France, R. Agnew, T. Yan, M. Dhanoa, J. Dijkstra, D. Beever, and C. Reynolds. 2003. Alternatives to linear analysis of energy balance data from lactating dairy cows. J. Dairy Sci. 86:2904-2913

Kertz, A. F. 1998. Variability in delivery of nutrients to lactating dairy cows. J. Dairy Sci. 81:3075-3084

Klinedinst, P. L., D. A. Wilhite, G. L. Hahn, and K. G. Hubbard. 1993. The potential effects of climate change on summer season dairy cattle milk production and reproduction. Clim. Change 23:21-36. 
Lidback, J., and C. Laughton. 2012. 2011 Northeast Dairy Farm Summary. Accessed May 5, 2013. http://www.dairychallenge.org/ pdfs/2011_Northeast/2011DairyFarmSummary.pdf.

McKibben, B. 2007. Climate change 2007: The physical science basis: Summary for policymakers. New York Rev. Books 54:44-45.

Nardone, A., B. Ronchi, N. Lacetera, M. S. Ranieri, and U. Bernabucci. 2010. Effects of climate changes on animal production and sustainability of livestock systems. Livest. Sci. 130:57-69.

NCDC (National Climate Data Center). 2010. Monthly Observational Data. NCDC, National Oceanic and Atmospheric Association, Washington, DC.

NOAA (National Oceanic and Atmospheric Administration). 2011 Global Historical Climatology Network: Daily Database. National Climate Data Center, National Oceanic and Atmospheric Association, Washington, DC.

NRC. 2001. Nutrient Requirements of Dairy Cattle. 7th ed. Natl. Acad. Press, Washington, DC

Spilke, J., and R. Fahr. 2003. Decision support under the conditions of automatic milking systems using mixed linear models as part of a precision dairy farming concept. Pages $780-785$ in Proc. EFITA Congr., Debrecen, Hungary. European Federation for Information Technology in Agriculture, Food and the Environment (EFITA), Paris, France.

St-Pierre, N. R., B. Cobanov, and G. Schnitkey. 2003. Economic losses from heat stress by US livestock industries. J. Dairy Sci. 86(ESuppl.):E52-E77.

Strathe, A B., J. Dijkstra, J. France, S. Lopez, T. Yan, and E. Kebreab. 2011. A Bayesian approach to analyze energy balance data from lactating dairy cows. J. Dairy Sci. 94:2520-2531.

Tylutki, T. P., D. G. Fox, V. M. Durbal, L. O. Tedeschi, J. B. Russell, M. E. Van Amburgh, T. R. Overton, L. E. Chase, and A. N. Pell. 2008. Cornell Net Carbohydrate and Protein System: A model for precision feeding of dairy cattle. Anim. Feed Sci. Technol. $143: 174-202$
USDA-APHIS (USDA Animal and Plant Health Inspection Service). 2007. Part 1. Reference of Dairy Cattle Health and Management Practices in the United States, 2007. USDA-APHIS, Fort Collins, CO.

USDA-ERS (USDA-Economic Research Service). 2012. Data and Statistics. Accessed May 2012. http://quickstats.nass.usda.gov/.

Wang, S. J., D. G. Fox, D. J. Cherney, L. E. Chase, and L. O. Tedeschi. 2000a. Whole-herd optimization with the Cornell net carbohydrate and protein system. II. Allocating homegrown feeds across the herd for optimum nutrient use. J. Dairy Sci. 83:2149-2159.

Wang, S. J., D. G. Fox, D. J. Cherney, L. E. Chase, and L. O. Tedeschi. 2000b. Whole-herd optimization with the Cornell Net Carbohydrate and Protein System. III. Application of an optimization model to evaluate alternatives to reduce nitrogen and phosphorus mass balance. J. Dairy Sci. 83:2160-2169.

Weiss, W. P., D. Shoemaker, L. McBeth, P. Yoder, N. St-Pierre, and M. Eastridge. 2012. Within farm variation in nutrient composition of feeds. Pages 103-117 in Proc. Tri-State Dairy Nutrition Conf., Fort Wayne, IN. The Ohio State University, Columbus.

West, J. W. 2003. Effects of heat-stress on production in dairy cattle. J. Dairy Sci. 86:2131-2144

West, J. W.. G. M. Hill, J. M. Fernandez, P. Mandebvu, and B. G. Mullinix. 1999. Effects of dietary fiber on intake, milk yield and digestion by lactating dairy cows during cool or hut, humid weather. J. Dairy Sci. 82:2455-2465.

Wheelock, J. B., R. P. Rhoads, M. J. VanBaale, S. R. Sanders, and L. H. Baumgard. 2010. Effects of heat stress on energetic metabolism in lactating Holstein cows. J. Dairy Sci. 93:644-655.

Young, B. A. 1981. Cold stress as it affects animal production. J. Anim. Sci. 52:154-163.

Young, B. A. 1983. Ruminant cold stress: Effect on production. J. Anim. Sci. 57:1601-1607. 